\title{
APLIKASI UAV (UNMANNED AERIAL VEHICLE) UNTUK MONITORING ZONA PANTAI
}

Dio Mega Putri dan Ahmad Perwira Mulia

Universitas Sumatera Utara (USU) Indonesia

Email: diomegap93@gmail.com dan a.perwira.mulia@gmail.com

\begin{tabular}{l}
\hline INFO ARTIKEL \\
\hline Diterima \\
25 Agustus 2021 \\
Direvisi \\
05 September 2021 \\
Disetujui \\
15 September 2021 \\
\hline
\end{tabular}

Kata Kunci: zona pantai; $\quad G C P$; teknologi $U A V$

\begin{abstract}
ABSTRAK
Salah satu fungsi manajemen zona pantai adalah untuk menjaga kestabilan pantai sehingga sangat memerlukan data monitoring zona pantai. Namun, data monitoring dan penelitian tentang kondisi zona pantai dan perubahan garis pantai masih sedikit. Pesatnya perkembangan teknologi mengakibatkan pekerjaan survei dan pemetaan zona pantai kini dapat dilakukan dengan mudah, yaitu dengan menggunakan teknologi $U A V$. Penelitian ini bertujuan untuk menganalisis kondisi zona pantai berdasarkan ortofoto yang diambil oleh $U A V$ yang dikontrol dengan menggunakan GPS Geodetik di lapangan dan menguraikan tahapan pembentukan fotogrametri dengan $U A V$ hingga menghasilkan gambar ortofoto yang terkoreksi. Metodologi yang diterapkan dalam penelitian ini terdiri dari prasurvei, survei lapangan dan pasca survei. Tahapan awal penelitian meliputi persiapan teknis dan non teknis, pengamatan area survey dan melakukan studi referensi. Tahapan survei lapangan dilakukan untuk mengumpulkan data primer berupa hasil pengukuran Ground Control Point (GCP) dan pengambilan mosaik foto udara menggunakan UAV/Drone, mengambil foto dokumentasi lapangan, serta memenuhi kebutuhan survei lainnya. Tahapan pasca survei merupakan kegiatan pengolahan data foto udara serta pengolahan foto dokumentasi. Nilai ketentuan ketelitian geometri berdasarkan kelas (CE90 dan LE90) termasuk ke dalam kelas 1. Berdasarkan hasil perhitungan selisih jarak beberapa objek di foto pada komputer dan jarak sebenarnya di lapangan, diperoleh rata-rata persentase akurasi sebesar 97\%. Hal tersebut menandakan bahwa pengukuran menggunakan $U A V$ memiliki akurasi yang tinggi. $U A V$ merupakan alat yang ideal untuk survei dan pemetaan zona pantai serta masalah pantai lainnya.
\end{abstract}

\section{ABSTRACT}

One of the functions of coastal zone management is to maintain the stability of the coast, so it requires monitoring data for the coastal zone. However, monitoring and research data on

$\begin{array}{ll}\text { How to cite: } & \text { Putri, D. M., \& Mulia, A. P. (2021) Aplikasi UAV (Unmanned Aerial Vehicle) untuk Monitoring } \\ & \text { Zona Pantai. Jurnal Syntax Admiration 2(9). https://doi.org/10.46799/jsa.v2i9.309 } \\ \text { E-ISSN: } & \text { 2722-5356 } \\ \text { Published by: } & \text { Ridwan Institute }\end{array}$




coastal zone conditions and shoreline changes are still scant.
The rapid development of technology make surveying and
mapping of coastal zones can now be done easily, using UAV
technology. This study aims to analyze the condition of the
coastal zone based on orthophoto taken by UAV controlled
using GPS Geodetic in the field and describe the stages of
photogrammetry formation with the UAV to produce corrected
orthophoto images. The methodology applied in this study
consisted of pre-survey, field survey and post-survey. The
initial stages of the research include technical and non-
technical preparation, observing the survey area and
conducting reference studies. The field survey stage is carried
out to collect primary data in the form of the results of Ground
Control Point (GCP) measurements and take aerial photo
mosaics using UAV/Drones, take photos of field
documentation, and fulfill other survey needs. The post-survey
stage is the activity of processing aerial photo data and
processing photo documentation. The value of the provisions
for geometric accuracy based on class (CE90 and LE90) is
included in class 1. From the calculation of the difference in
the distance of some objects in the photo on the computer and
the actual distance in the field, the average percentage of
accuracy is 97\%. This indicates that the measurement using a
UAV has a high accuracy. UAVs are an ideal tool for
surveying and mapping coastal zones and other coastal issues.
technology $;$ Coastal $;$ UAV

\section{Pendahuluan}

Zona pantai adalah antarmuka antara darat dan laut yang didefinisikan sebagai bagian dari daratan yang masih dipengaruhi oleh sifat-sifat laut, seperti pasang surut, angin laut dan gelombang. Serta meliputi bagian laut yang masih dipengaruhi oleh proses-proses alami yang terjadi di darat seperti sedimen pembentuk pantai dan angkutan endapan, maupun kegiatan yang disebabkan oleh kegiatan manusia di darat, seperti penggundulan hutan dan pencemaran (Dahuri et al., 2001).

Pemantauan zona pantai merupakan tugas penting dalam perlindungan lingkungan, sedangkan deteksi garis pantai sangat penting untuk pengelolaan pesisir (Kolednik, 2014). Pengelolaan pesisir memerlukan informasi akurat terkini karena pergerakan pesisir merupakan hal yang utama dalam mengevaluasi erosi pantai. Sifat dinamis dari zona pesisir merupakan aspek yang yang sangat menantang dalam pengelolaan zona pesisir. Tujuan pengelolaan wilayah pesisir adalah untuk menyeimbangkan kepentingan di wilayah pesisir tersebut yang terkait dengan keselamatan, lingkungan, ekonomi, aktivitas manusia serta nilai estetika dan budaya.

Salah satu fungsi manajemen zona pantai adalah untuk menjaga kestabilan pantai sehingga sangat memerlukan data monitoring zona pantai (Kolednik, 2014). Namun, data monitoring dan penelitian tentang kondisi zona pantai dan perubahan garis pantai sangatlah minim. Hal ini terutama disebabkan oleh masih relatif lama dan mahalnya 
biaya survei dan pemetaan pantai bila dilakukan dengan metode konvensional, misalnya dengan menggunakan Total Station ataupun GPS Geodetik.

Pesatnya perkembangan teknologi mengakibatkan pekerjaan survei dan pemetaan zona pantai kini dapat dilakukan dengan mudah, yaitu dengan menggunakan teknologi $U A V$. Beberapa tahun terakhir, penggunaan $U A V$ sebagai alat pemetaan dan survei telah berkembang secara signifikan dan sebagai hasilnya potensi aplikasi rekayasa pesisir mulai terwujud (Drummond et al., 2015).

Unmanned Aerial Vehicle $(U A V)$ atau Drone yang dilengkapi dengan kamera digital ringan sehingga dapat mengambil gambar muka bumi dengan kualitas yang baik. Semua gambar-gambar yang diambil melalui $U A V$ memiliki skala yang seragam dan berbasis pada sistem koordinat yang sama karena telah dikoreksi secara geometri. Selanjutnya gambar-gambar tersebut digabungkan untuk membentuk mosaik yang tegak (orthomosaic) yang menjadi dasar pembuatan peta yang cukup akurat.

$U A V$ dilengkapi dengan unit GPS yang ringan, yang sangat andal dan dapat mengisi jika terdapat celah pada peta, dengan kata lain, pemetaan dengan $U A V$ dapat mengisi celah peta yang tidak dapat dicakup oleh peta satelit seperti Google.

Sebagian besar keuntungan nyata dari $U A V$ dalam pemetaan fotogrametri umum berlaku untuk survei pantai. Keunggulan ini termasuk biaya perangkat keras yang relatif rendah, otomatisasi survei fotografi tingkat tinggi dan biaya pengoperasian yang sangat rendah. Selain itu, kemungkinan melihat langsung fotografi di lapangan dengan memungkinkan pengulangan jika terdeteksi kesalahan dan risiko keamanan yang sangat rendah jika terjadi kecelakaan karena bobot yang ringan dari perangkat ini adalah bagian dari banyak keuntungan lain menggunakan UAV (Gonçalves \& Henriques, 2015). Pemetaan dengan $U A V$ menjadi salah satu solusi untuk memetakan wilayah di Indonesia yang beragam topografinya (Purwanto, 2017). Sumber Daya Manusia (SDM) yang terampil mampu menghasilkan produk fotogrametri UAV dengan kualitas yang baik, biaya lebih murah, cepat dan aman (Saadatseresht et al., 2015). Teknologi ini merupakan salah satu alternatif yang dapat diandalkan untuk menghasilkan peta berbasis foto udara digital beresolusi tinggi yang mampu menggabungkan metode pemetaan terestris, efisien dalam hal biaya dan murah diaplikasikan (Rokhmana, 2013).

Penggunaan $U A V$ telah digunakan pada penelitian-penelitian sebelumnya. Seperti yang dilakukan oleh (Basith et al., 2015) dalam pemetaan pelabuhan perikanan Pantai Sadeng kabupaten Gunungkidul. Selain itu, (Maulana et al., 2017) juga melakukan uji akuisisi data dengan $U A V$ untuk monitoring kondisi mangrove dalam mencegah abrasi air laut. (Maulana \& Wulan, 2015) juga melakukan penelitian mengenai pemotretan udara dengan $U A V$ untuk mendukung kegiatan konservasi kawasan Gumuk Pasir Parangtritis. Selain itu (Putra et al., 2016) dalam jurnalnya melakukan uji akuisisi dara dengan $U A V$ untuk monitoring kondisi mangrove dalam mencegah abrasi air laut. Berdasarkan hasil interpretasi foto udara dan survei lapangan dapat disimpulkan bahwa tanaman mangrove tersebar merata di kawasan Pantai Baros. Persebaran tersebut menunjukan bahwa ekosistem mangrove di Baros masih terjaga. Salah satu faktor utama yang menyebabkan tanaman mangrove tetap lestari adalah karena kawasan Baros 
ditetapkan sebagai kawasan konservasi. (Junarto et al., 2020) juga melakukan pemanfaatan teknologi UAV untuk pemetaan kadaster. Hasil analisis yang telah dibahas dengan software fotogrametri dapat menghasilkan peta orthophoto dan DEM mencakup seluruh area pemetaan dengan resolusi spasial fraksi centimeter dan masuk kedalam ketelitian Peta Dasar Pertanahan skala 1:1000.

Tujuan penelitian ini adalah untuk menganalisis kondisi zona pantai kawasan Pantai Cermin berdasarkan ortofoto yang diambil dengan UAV yang dikontrol dengan menggunakan GPS Geodetik di lapangan dan menguraikan tahapan pembentukan fotogrametri dengan $U A V$ hingga menghasilkan gambar ortofoto yang terkoreksi. Hasil penelitian ini diharapkan dapat menjadi referensi bagi Pemerintah Terkait penggunaan $U A V$ untuk memetakan dan mensurvei suatu wilayah.

\section{Metode Penelitian}

Metodologi yang diterapkan dalam penelitian ini terdiri dari prasurvei, survei lapangan dan pasca survei. Adapun tahapan awal penelitian ini meliputi persiapan teknis dan non teknis, pengamatan area survei dan melakukan studi referensi. Tahapan survei lapangan dilakukan untuk mengumpulkan data primer berupa: hasil pengukuran Ground Control Point (GCP) dan pengambilan mosaik foto udara menggunakan wahana UAV/Drone, mengambil foto dokumentasi lapangan, serta memenuhi kebutuhan survei lainnya. Adapun tahapan pasca survei merupakan kegiatan pengolahan data foto udara, pengolahan foto dokumentasi dan penyusunan laporan.

Penelitian dilakukan secara eksploratif, kuantitatif dan kualitatif. Artinya, datadata penelitian yang diperoleh diolah secara kuantitatif dengan menggunakan persamaan-persamaan yang relevan dan hasilnya akan dijelaskan secara kualitatif.

Lokasi pengamatan lapangan adalah kawasan Pantai Cermin, Kabupaten Serdang Bedagai yang meliputi daerah hamparan sempadan pantai, yakni daerah tepi pantai menuju daratan (daerah sempadan pantai) yang diukur sepanjang $2 \mathrm{Km}$ dari arah memanjang pantai.

Pengolahan data dilakukan di Laboratorium Survei dan Geospasial (IUT) yang ada di Departemen Teknik Sipil, FT USU. Proses pemetaan kawasan Pantai Cermin dalam penelitian ini diperlihatkan pada diagram alir gambar 1. 


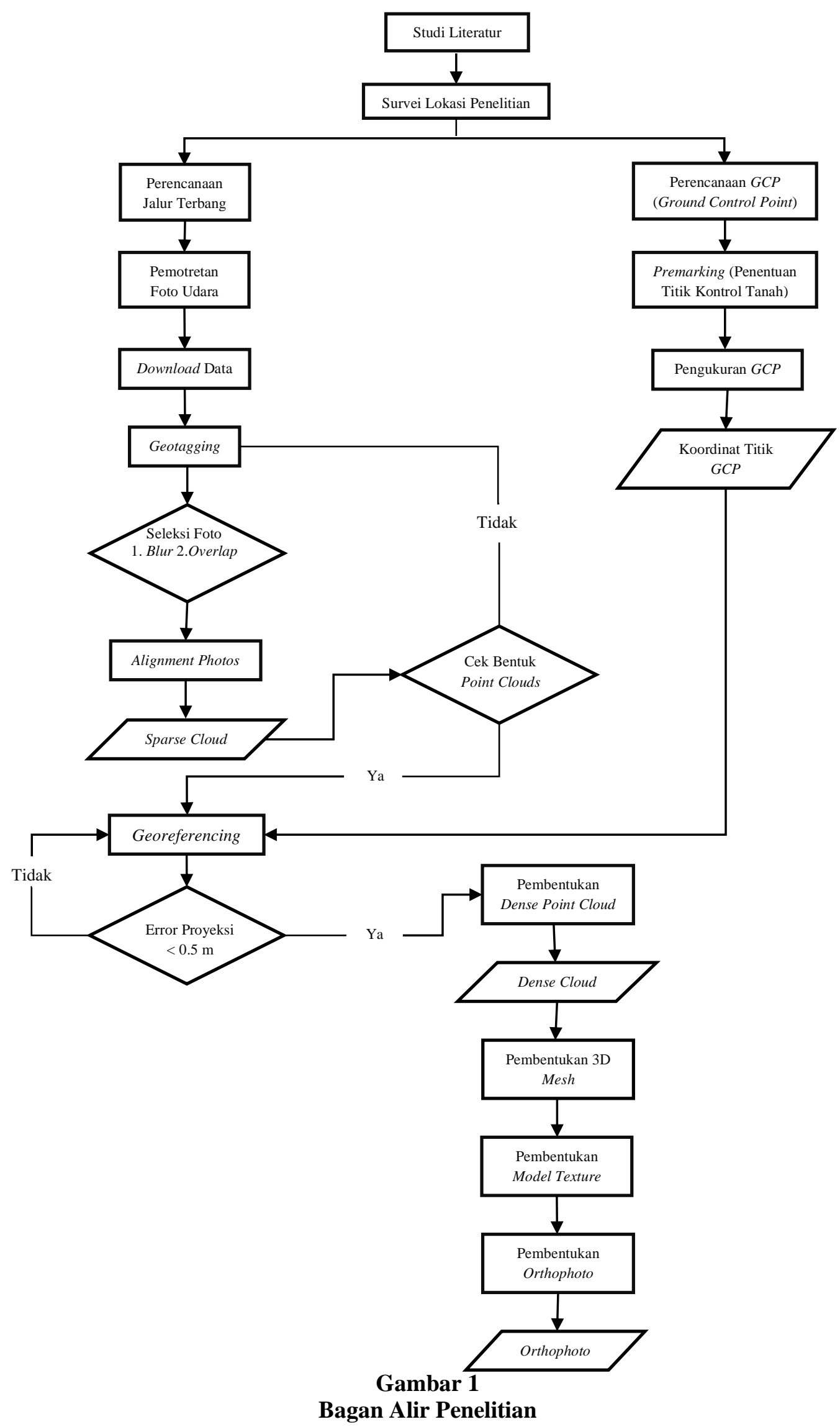


Ruang lingkup pemetaan kawasan Pantai Cermin dengan $U A V$ dapat dijelaskan secara garis besar pada gambar 2 .

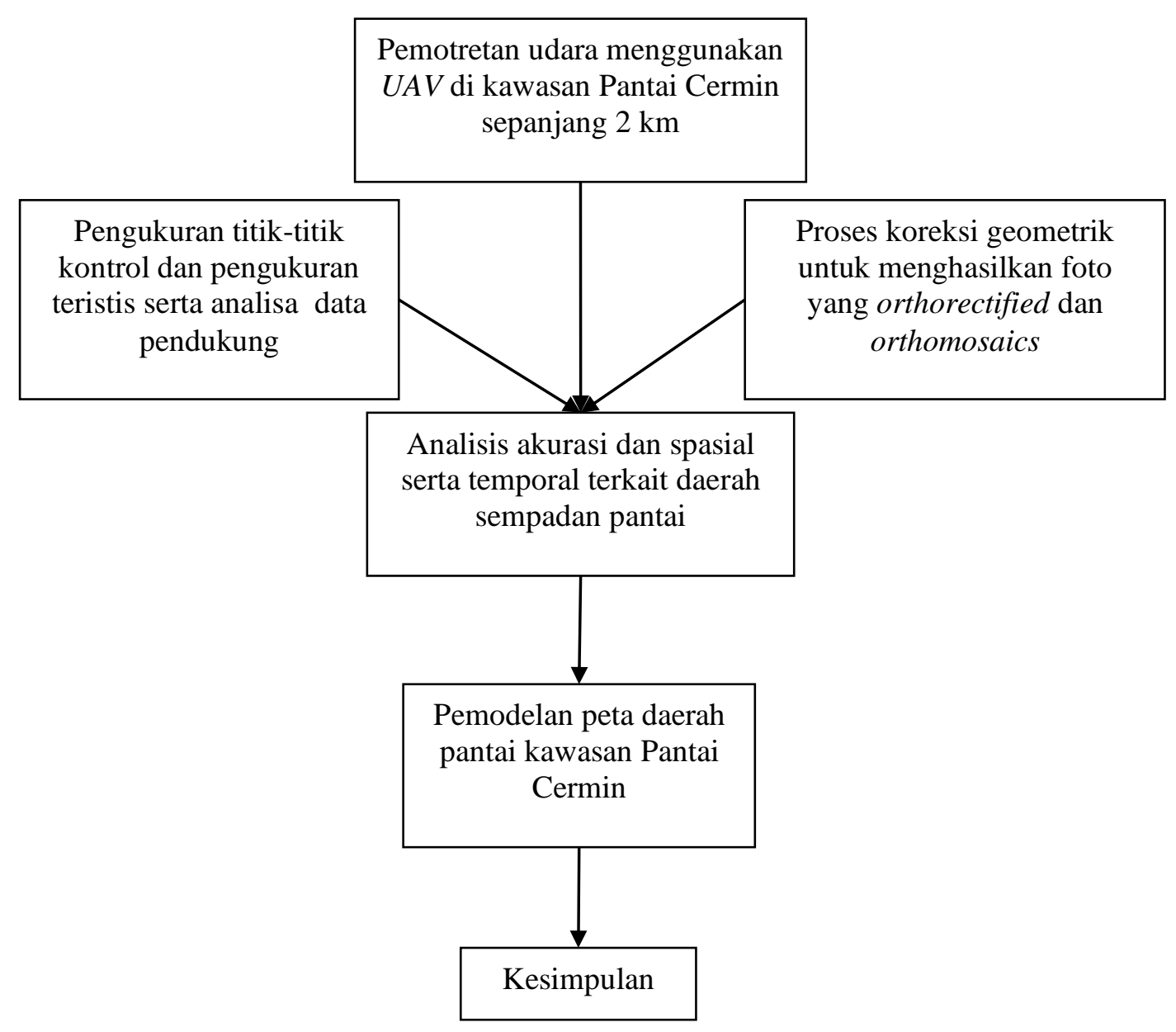

\section{Gambar 2 \\ Ruang Lingkup Penelitian Pemetaan}

\section{Hasil dan Pembahasan}

Pemetaan dilakukan pada kawasan Pantai Cermin. Pemetaan ini dilakukan menggunakan teknologi Drone DJI Phantom 4 Professional yang telah dilengkapi dengan gimbal dan kamera sederhana. Wilayah yang akan dilakukan pengambilan foto udara adalah daerah sempadan pantai pada kawasan pantai cermin atau lebih tepatnya di ujung Pantai Mutiara (muara sungai) sampai Pantai Gudang-Garam sepanjang $\pm 2 \mathrm{~km}$ dengan lebar sekitar 150 meter menuju ke arah daratan. Penelitian pertama ini telah dimulai sejak tahun 2018 dan penelitian kedua dilakukan pada tahun 2019, diawali dengan proses pengukuran topografi menggunakan alat GPS Geodetik hingga pada proses pemotretan foto udara menggunakan $U A V$. Cakupan wilayah penelitian dapat dilihat pada gambar 3 . 


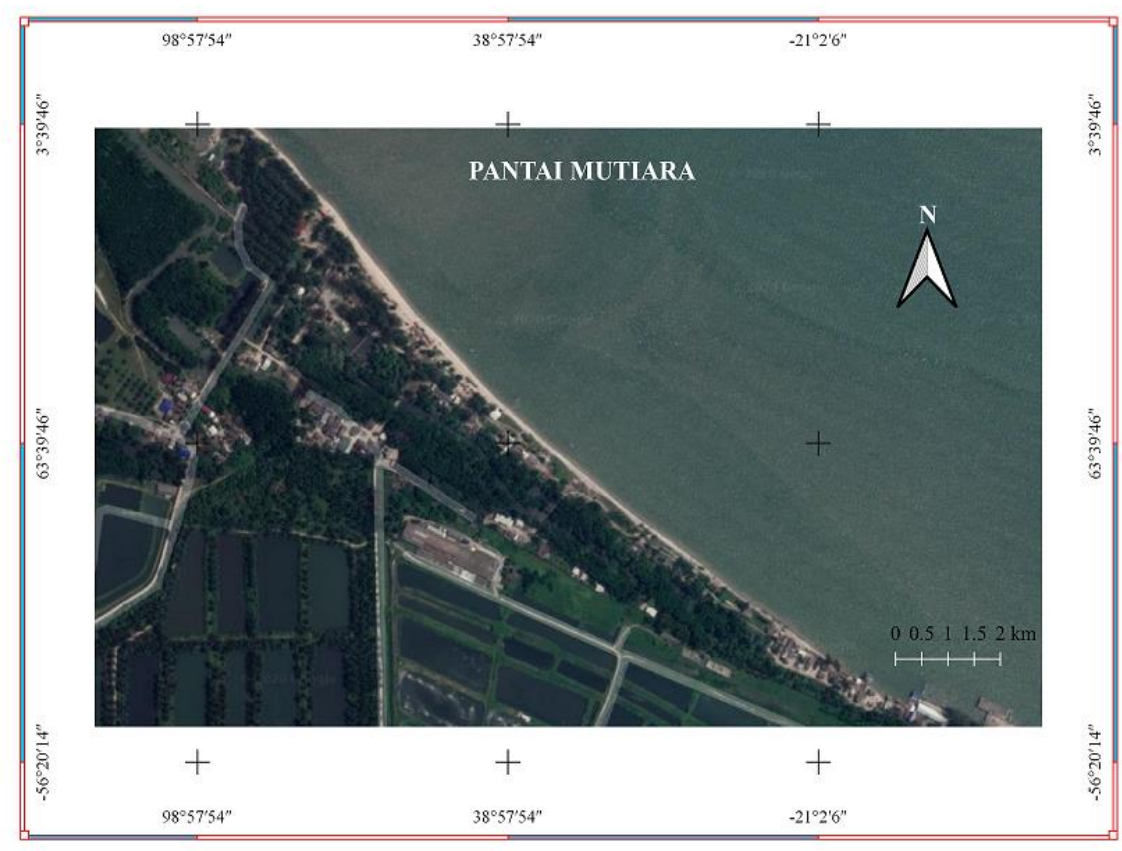

Gambar 3

Cakupan Wilayah Penelitian

\section{Hasil dan Analisis Pembentukan Peta Topografi}

Setelah data titik-titik kontrol tanah dan semua foto udara berhasil di dapat, dilakukan pengolahan komputasi data di laboratorium menggunakan software Agisoft Photoscan.

Agisoft PhotoScan merupakan software untuk pemodelan 3D dari gambar atau foto yang direkam secara stereo di mana objek yang akan direkonstruksi terlihat pada setidaknya dua foto dengan kondisi foto baik diketahui posisi kameranya maupun tidak. Proses rekonstruksi 3D sepenuhnya dilakukan secara otomatis (Agisoft, 2016). Agisoft dapat digunakan untuk mengolah foto udara yang direkam menggunakan UAV/Drone, sehingga dari hasil perekamannya dapat dihasilkan mosaik ortofoto. Hasil ortofoto inilah yang akan menjadi data kondisi eksisting sebaran objek dan lingkungan. Hasil foto yang detail memiliki ketelitian yang baik. Selain mendapatkan gambaran kondisi eksisting juga dapat menjadi data dasar dalam pengolahan kebutuhan data terkait kawasan yaitu monitoring, rencana pengembangan, maupun upaya-upaya pelestarian lainnya titik tinggi (elevation point clouds) dan DEM resolusi tinggi serta dapat ditampilkan 3D. Proses pembuatan ortofoto dan DEM di dalam Agisoft Photoscan melalui beberapa tahapan, yaitu import foto dan rekonstruksi jalur terbang, align photos, input GCP dan ortorektifikasi, optimisasi alignment, pembangunan titik tinggi (Dense Point Cloud), pembangunan model 3D (mesh), pembangunan model texture, pembangunan DEM (Digital Elevation Model) dan pembangunan ortofoto. 


\section{Hasil Pembangunan Ortomosaik}

Pengolahan fotogrametri dengan jumlah foto udara yang sangat banyak tidak memungkinkan jika pengolahan dilakukan secara sekaligus, oleh karena itu pengolahan foto udara dibagi dalam beberapa segmen misi. Pengolahan data foto udara pada penelitian ini secara keseluruhan terbagi menjadi 4 segmen misi pengolahan. Selanjutnya dilakukan penggabungan kembali menggunakan software Agisoft Photoscan. Tujuan dari penggabungan ini adalah guna mendapatkan bentuk utuh daerah sempadan pantai yang menjadi tujuan penelitan. Bentuk peta ortomosaik Pantai Mutiara tahun 2019 dapat dilihat pada gambar 4 dan peta ortomosaik Pantai Mutiara tahun 2018 dapat dilihat pada gambar 5.

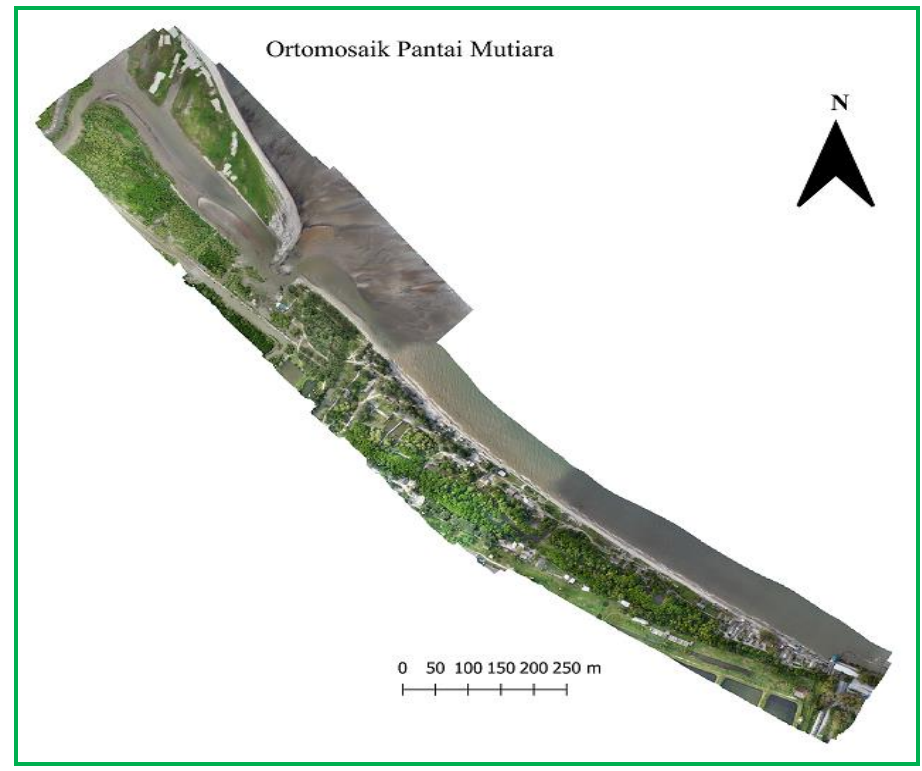

Gambar 3

Peta Ortomosaik Pantai Mutiara tahun 2019

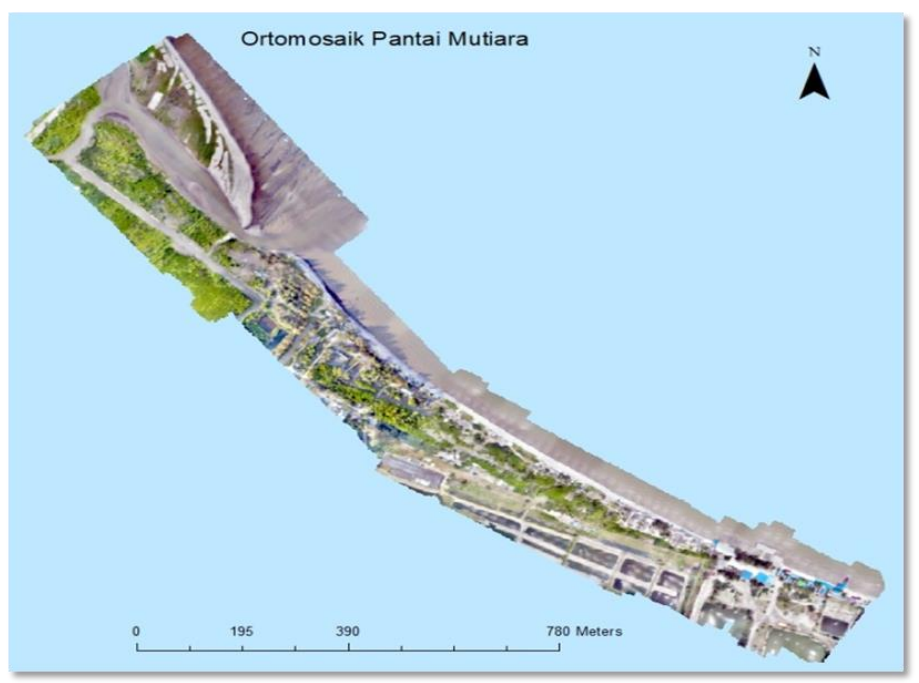

Gambar 4

Peta Ortomosaik Pantai Mutiara Tahun 2018 


\section{Uji Akurasi pada Mosaik Foto Udara dan DTM}

Pengujian akurasi pada foto udara perlu dilakukan agar data yang diperoleh dari foto udara bisa dikatakan sesuai dengan kondisi di lapangan. Secara teknis perhitungan akurasi dilakukan dengan memperbandingkan data hasil klarifikasi dengan data lapangan (Ibrahim, 2014).

RMSE atau yang dikenal dengan RMS residual adalah nilai perbedaan antara nilai sesungguhnya dengan nilai hasil ukuran (Zald et al., 2006). RMSE merupakan ukuran akurasi dari suatu prediksi besaran. Semakin besar nilai RMSE, maka semakin besar kesalahan hasil ukuran terhadap nilai yang dianggap benar.

Hasil nilai RMSE horizontal dan vertikal serta nilai akurasinya disajikan pada Tabel di bawah.

Tabel 1

Tabulasi nilai $R M S E$ horizontal

dan vertikal setiap misi tahun 2019

\begin{tabular}{ccc}
\hline \multirow{2}{*}{ Ortomosaik } & \multicolumn{2}{c}{ RMSE } \\
\cline { 2 - 3 } & Horizontal $(\mathbf{m})$ & Vertikal $(\mathbf{m})$ \\
\hline Misi 1 & 0.074075673 & 0.015915313 \\
\hline Misi 2 & 0.071597742 & 0.015708244 \\
\hline Misi 3 & 0.054951351 & 0.008263292 \\
\hline Misi 4 & 0.048998073 & 0.02112076 \\
\hline
\end{tabular}

Tabulasi nilai akurasi horizontal setiap misi tahun 2019 dapat dilihat pada Tabel 2.

Tabel 2

Tabulasi Nilai Akurasi Horizontal Setiap Misi Tahun 2019

\begin{tabular}{cc}
\hline Akurasi Horizontal CE90 & $\mathbf{1 , 5 1 7 5} \times \mathbf{R M S E}$ \\
\hline Misi 1 & 0.112409833 \\
\hline Misi 2 & 0.108649573 \\
\hline Misi 3 & 0.083388675 \\
\hline Misi 4 & 0.074354575 \\
\hline
\end{tabular}

Tabulasi Nilai Akurasi Vertikal Setiap Misi Tahun 2019 Dapat Dilihat Pada Tabel 3.

Tabel 3

Tabulasi Nilai Akurasi Vertikal Setiap Misi Tahun 2019

\begin{tabular}{cc}
\hline Akurasi Vertikal $\mathbf{L E 9 0}$ & $\mathbf{1 , 6 4 9 9} \mathbf{x}$ RMSE \\
\hline Misi 1 & 0.026258675 \\
\hline Misi 2 & 0.025917032 \\
\hline Misi 3 & 0.013633605 \\
\hline Misi 4 & 0.034847142 \\
\hline
\end{tabular}

Ketelitian Geometri Berdasarkan Kelas Tahun 2019 Dapat Dilihat Pada Tabel 4. 
Tabel 4

Ketelitian Geometri Berdasarkan

Kelas Tahun 2019

\begin{tabular}{ccccc}
\hline Ketelitian & Hasil Uji & \multicolumn{3}{c}{ Ketelitian Peta 1:1000 } \\
\cline { 3 - 5 } & $\begin{array}{l}\text { CE90 dan } \\
\text { LE90 (m) }\end{array}$ & Kelas 1 & Kelas 2 & Kelas 3 \\
\hline Horizontal & 0.112409833 & 0.2 & 0.3 & 0.5 \\
\hline & 0.108649573 & 0.2 & 0.3 & 0.5 \\
\hline & 0.083388675 & 0.2 & 0.3 & 0.5 \\
\hline Vertikal & 0.074354575 & 0.2 & 0.3 & 0.5 \\
\hline & 0.026258675 & 0.2 & 0.3 & 0.5 \\
\hline & 0.025917032 & 0.2 & 0.3 & 0.5 \\
\hline & 0.013633605 & 0.2 & 0.3 & 0.5 \\
\hline & 0.034847142 & 0.2 & 0.3 & 0.5 \\
\hline
\end{tabular}

Tabel 4 di atas menjelaskan hasil uji CE90 dan LE90 untuk ketelitian peta skala 1:1000 memenuhi standar kelas ' 1 ' yang telah ditentukan Peraturan Kepala Badan Informasi Geospasial No. 15 Tahun 2014 Tentang Pedoman Teknis Ketelitian Peta Dasar, dengan demikian ortomosaik dan DTM penelitian ini dapat digunakan untuk pemetaan skala 1:1000.

Tabulasi nilai RMSE horizontal dan vertikal setiap misi tahun 2018 dapat dilihat pada Tabel 5.

Tabel 5

Tabulasi Nilai RMSE Horizontal Dan Vertikal Setiap Misi Tahun 2018

\begin{tabular}{ccc}
\hline \multirow{2}{*}{ Ortomosaik } & \multicolumn{2}{c}{ RMSE } \\
\cline { 2 - 3 } & Horizontal (m) & Vertikal (m) \\
\hline Misi 1 & 0.079298602 & 0.065506001 \\
\hline Misi 3 & 0.069635273 & 0.034192422 \\
\hline Misi 4 & 0.088140262 & 0.014585953 \\
\hline
\end{tabular}

Tabulasi Nilai Akurasi Horizontal Setiap Misi Tahun 2018 Dapat Dilihat Pada Tabel 6.

Tabel 6

Tabulasi Nilai Akurasi Horizontal Setiap Misi Tahun 2018

\begin{tabular}{cc}
\hline $\begin{array}{c}\text { Akurasi Horizontal } \\
\text { CE90 }\end{array}$ & $\mathbf{1 . 5 1 7 5}$ x RMSE \\
\hline Misi 1 & 0.120335629 \\
\hline Misi 3 & 0.105671527 \\
\hline Misi 4 & 0.133752848 \\
\hline
\end{tabular}

Tabulasi Nilai Akurasi Vertikal Setiap Misi Tahun 2018 Dapat Dilihat Pada Tabel 7. 
Tabel 7

Tabulasi Nilai Akurasi

Vertikal Setiap Misi Tahun 2018

\begin{tabular}{cc}
\hline $\begin{array}{c}\text { Akurasi Horizontal } \\
\text { LE90 }\end{array}$ & $\mathbf{1 . 6 4 9 9} \times \mathbf{R M S E}$ \\
\hline Misi 1 & 0.108078351 \\
\hline Misi 3 & 0.174347452 \\
\hline Misi 4 & 0.220678824 \\
\hline
\end{tabular}

Ketelitian Geometri Berdasarkan Kelas Tahun 2018 Dapat Dilihat Pada Tabel 8.

Tabel 8

Ketelitian Geometri Berdasarkan Kelas

\begin{tabular}{|c|c|c|c|c|}
\hline \multirow[t]{2}{*}{ Ketelitian } & \multirow{2}{*}{$\begin{array}{l}\text { Hasil Uji CE90 dan } \\
\text { LE90 (m) }\end{array}$} & \multicolumn{3}{|c|}{ Ketelitian Peta 1:1000 } \\
\hline & & $\begin{array}{c}\text { Kelas } \\
1\end{array}$ & $\begin{array}{c}\text { Kelas } \\
2\end{array}$ & $\begin{array}{c}\text { Kelas } \\
3\end{array}$ \\
\hline \multirow{3}{*}{ Horizontal } & 0.120335629 & 0.2 & 0.3 & 0.5 \\
\hline & 0.105671527 & 0.2 & 0.3 & 0.5 \\
\hline & 0.133752848 & 0.2 & 0.3 & 0.5 \\
\hline \multirow[t]{3}{*}{ Vertikal } & 0.108078351 & 0.2 & 0.3 & 0.5 \\
\hline & 0.220678824 & 0.2 & 0.3 & 0.5 \\
\hline & 0.220678824 & 0.2 & 0.3 & 0.5 \\
\hline
\end{tabular}

Dalam pengujian perbandingan ini dilakukan dengan menghitung selisih jarak pada sampel. Sampel yang menjadi bahan perbandingan adalah jarak beberapa obyek yang telah ditentukan sebelumnya dan terdapat sembilan titik pengukuran. Interpretasi pada salah satu sisi dermaga dapat dilihat pada gambar 6 dan gambar 7 .

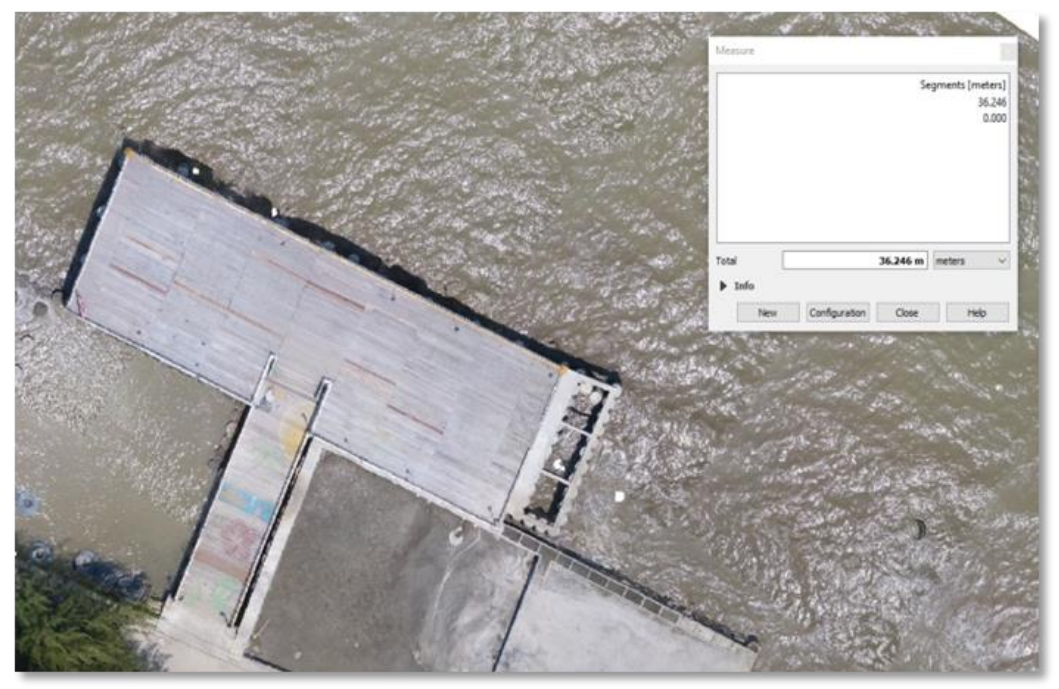

Gambar 5

Interpretasi Pada Salah Satu Sisi Dermaga 


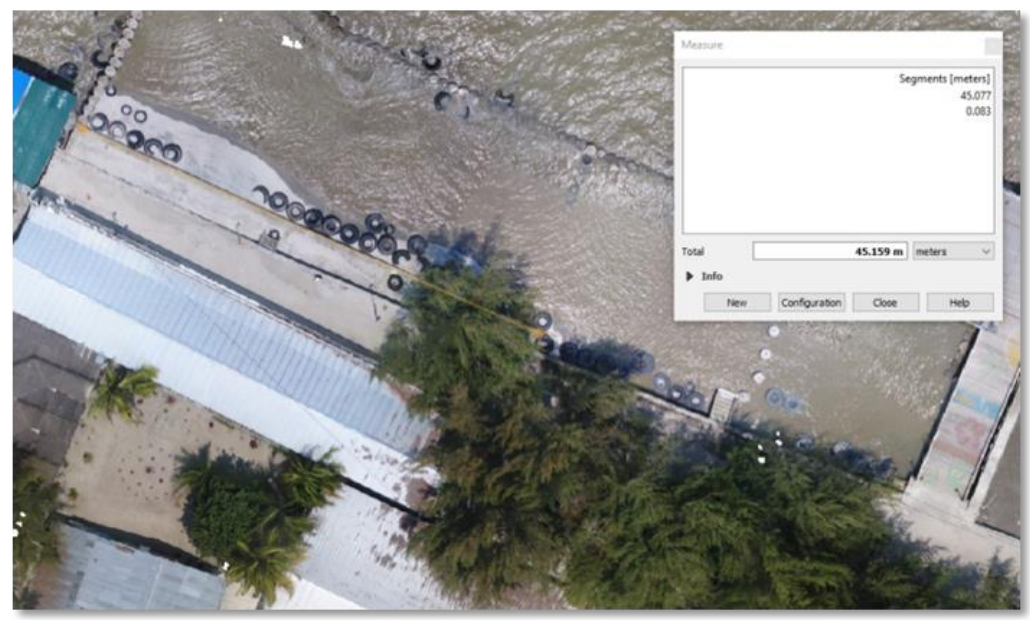

Gambar 6

Interpretasi Pada Sebuah Beton Breakwater

Persamaan yang digunakan adalah sebagai berikut:

Akurasi $=\left[1-\left[\frac{\Delta}{\text { Lapangan }}\right]\right] x 100 \%$

di mana $\Delta=$ lab - lapangan

Hasil perbandingan jarak objek pada gambar dan lapangan dapat dilihat pada tabel 9.

Tabel 9

Hasil Perbandingan Jarak Objek

Pada Gambar Dan Lapangan

\begin{tabular}{cccccc}
\hline No & Keterangan Objek & \multicolumn{2}{c}{ Jarak } & $\Delta$ & Akurasi \\
\cline { 3 - 4 } & & $\begin{array}{c}\text { Interpretasi } \\
(\mathbf{m})\end{array}$ & $\begin{array}{c}\text { Lapangan } \\
(\mathbf{m})\end{array}$ & & \\
\hline 1 & Dermaga Sisi 1 & 36,44 & 35,50 & 0,94 & $97 \%$ \\
\hline 2 & Dermaga Sisi 2 & 12,81 & 12,00 & 0,81 & $94 \%$ \\
\hline 3 & Dermaga Sisi 3 & 38,62 & 37,50 & 1,12 & $97 \%$ \\
\hline 4 & $\begin{array}{c}\text { Beton Breakwater } \\
\text { Sisi 1 }\end{array}$ & 21,58 & 21,20 & 0,38 & $98 \%$ \\
& & & & \\
\hline 5 & $\begin{array}{c}\text { Beton Breakwater } \\
\text { Sisi 2 }\end{array}$ & 15,82 & 15,40 & 0,42 & $97 \%$ \\
\hline 6 & $\begin{array}{c}\text { Beton Breakwater } \\
\text { Sisi 3 }\end{array}$ & 26,76 & 26,10 & 0,66 & $97 \%$ \\
\hline 7 & Beton Breakwater A & 31,08 & 30,30 & 0,78 & $97 \%$ \\
\hline 8 & Beton Breakwater B & 45,00 & 44,50 & 0,50 & $99 \%$ \\
\hline 9 & Beton Breakwater C & 21,53 & 22,00 & 0,47 & $98 \%$ \\
\hline
\end{tabular}

Tabel 9 di atas menunjukkan hasil perhitungan selisih jarak beberapa objek di foto pada komputer dan jarak sebenarnya di lapangan, maka diperoleh rata-rata persentase akurasi adalah sebesar 97\%. Hal tersebut menandakan bahwa pengukuran menggunakan $U A V$ memiliki akurasi yang tinggi. 
4. Menghitung Skala Foto Udara

Skala Foto Udara Tahun 2019

Dik : $\mathrm{f}=24 \mathrm{~mm}$

$\mathrm{H}=50 \mathrm{~m}$

$\mathrm{h}_{\text {avg }}=1.759 \mathrm{~m}$ (diambil dari rata-rata tinggi pada titik GCP)

Dit : $\mathrm{S}_{\text {avg }}$ ?

$\mathrm{S}_{\text {avg }}=\frac{\mathrm{f}}{\mathrm{H}-\mathrm{h}_{\text {avg }}}=\frac{24}{50-1759}=\frac{2,4}{3241}=\frac{1}{1350}=1: 1350$

Maka skala-rata pada gambar ortofoto adalah sebesar "1:1350".

Skala Foto Udara Tahun 2018

Dik : $\mathrm{f}=24 \mathrm{~mm}$

$\mathrm{H}=50 \mathrm{~m}$

Dit : $\mathrm{S}_{\text {avg }}$ ?

$\mathrm{S}_{\text {avg }}=\frac{\mathrm{f}}{\mathrm{H}-\mathrm{h}_{\text {avg }}}=\frac{24}{50-1916}=\frac{2,4}{3084}=\frac{1}{1285}=1: 1285$

Maka skala-rata pada gambar ortofoto adalah sebesar "1:1285".

5. Nilai Ground Sample Distance (GSD)

Ground Sample Distance (GSD) adalah nilai ukuran terkecil yang mampu terekam dalam satu piksel (Harintaka, 2012). GSD dan resolusi spasial memiliki pengertian yang sama.

Nilai Ground Sample Distance (GSD) yang diperoleh pada Peta Ortofoto setiap misi tahun 2019 dapat dilihat pada tabel 10.

Tabel 10

Nilai GSD Setiap Misi Tahun 2019

\begin{tabular}{cccc}
\hline \multicolumn{4}{c}{ Nilai GSD } \\
\hline Nama Misi & $\begin{array}{c}\text { Ketinggian 50 } \\
\mathbf{m}(\mathbf{c m} / \text { pixel })\end{array}$ & $\begin{array}{c}\text { Report } \\
(\mathbf{c m} / \text { pixel })\end{array}$ & $\begin{array}{c}\text { Peta Ortofoto } \\
(\mathbf{c m} / \text { pixel })\end{array}$ \\
\hline Misi 1 & 1,37 & 1,84 & 3 \\
\hline Misi 2 & 1,37 & 1,98 & 1,35 \\
\hline Misi 3 & 1,37 & 1,88 & 2,001 \\
\hline Misi 4 & 1,37 & 1,84 & 2,5 \\
\hline
\end{tabular}

Nilai Ground Sample Distance (GSD) yang diperoleh pada Peta Ortofoto setiap misi tahun 2018 dapat dilihat pada tabel 11.

Tabel 11

Nilai GSD Setiap Misi Tahun 2018

\begin{tabular}{cccc}
\hline \multicolumn{4}{c}{ Nilai GSD Setiap Misi Tahun 2018 } \\
\hline $\begin{array}{c}\text { Nama } \\
\text { Misi }\end{array}$ & $\begin{array}{c}\text { Ketinggian 50 m } \\
(\mathbf{c m} / \text { pixel })\end{array}$ & $\begin{array}{c}\text { Report } \\
(\mathbf{c m} / \text { pixel })\end{array}$ & $\begin{array}{c}\text { Peta } \\
\text { Ortofoto } \\
(\mathbf{c m} / \text { pixel })\end{array}$ \\
\hline Misi 1 & 1,37 & 1,50 & 2,251 \\
\hline Misi 2 & 1,37 & 1,46 & 2,019 \\
\hline Misi 3 & 1,37 & 1,40 & 2,284 \\
\hline Misi 4 & 1,37 & 1,36 & 2,284 \\
\hline
\end{tabular}




\section{Hasil Perbandingan Secara Visual}

Hasil perbandingan secara visual misi pertama Pantai Mutiara tahun 2019 dan tahun 2018 dapat dilihat pada gambar 8 dan gambar 9.

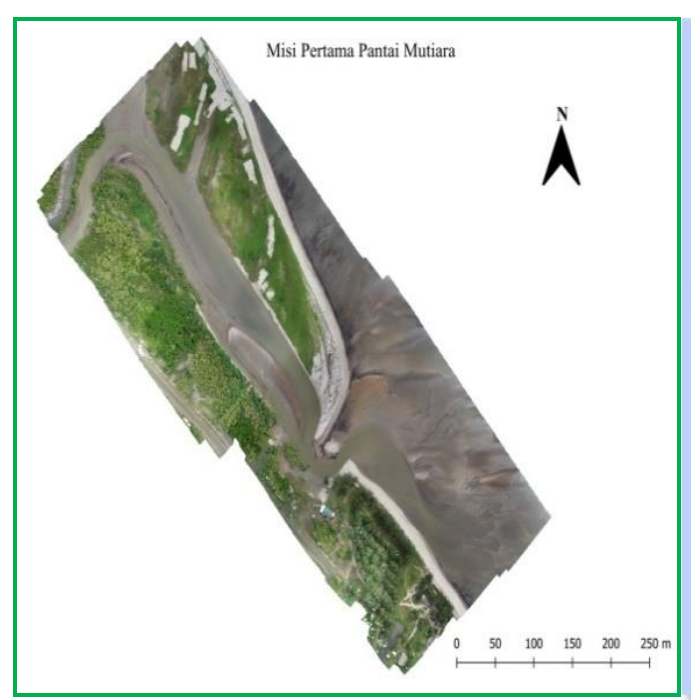

\section{Gambar 8}

Visualisasi Misi Pertama

Tahun 2019

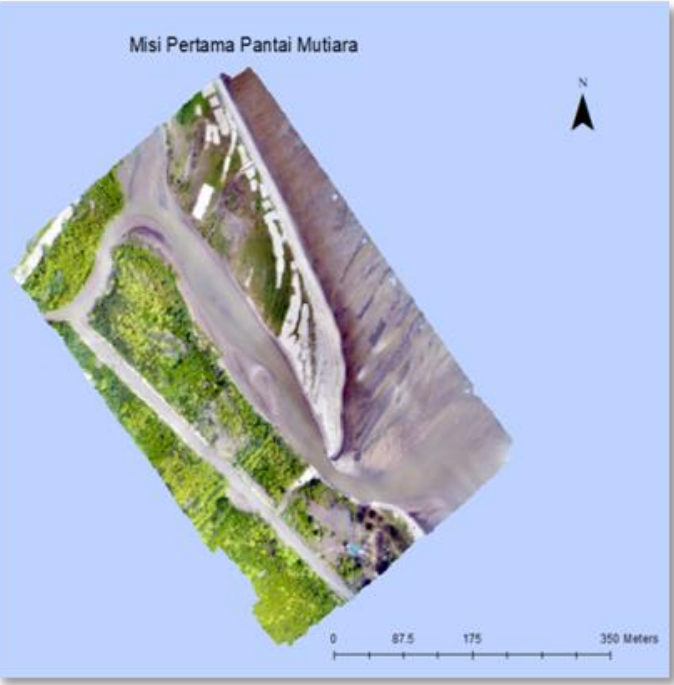

Gambar 9

Visualisasi Misi Pertama

Tahun 2018

Berdasarkan hasil analisis, pada daerah yang berbatasan langsung dengan muara sungai ini memiliki daerah garis pantai berupa lumpur. Vegetasi pada zona ini berupa pohon mangrove dan beberapa bagian terdapat semak belukar.

Hasil perbandingan secara visual misi kedua Pantai Mutiara tahun 2019 dan tahun 2018 dapat dilihat pada gambar 10 dan gambar 11.

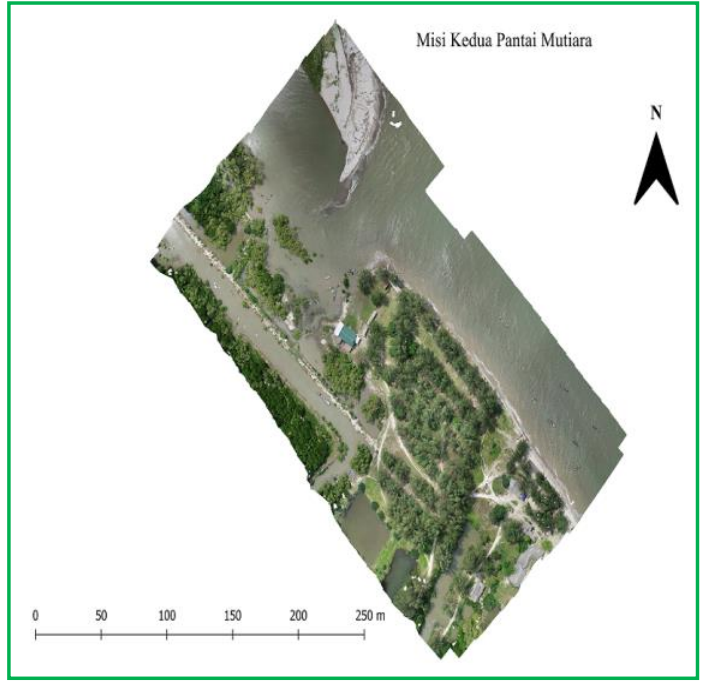

Gambar 10

Visualisasi Misi Kedua Tahun 2019 


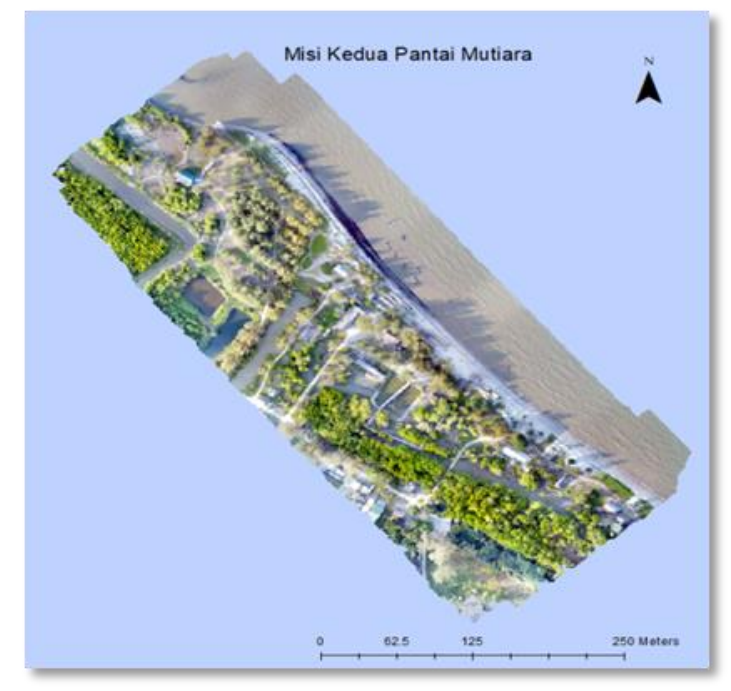

Gambar 11

Visualisasi Misi Kedua Tahun 2018

Berdasarkan gambar 11, pada tahun 2018 daerah sepanjang garis pantai dipenuhi dengan sampah. Sampah ini berasal dari muara sungai yang didominasi oleh kayu dan sampah plastik. Sedangkan pada tahun 2019 didominasi oleh pepohonan dan semak belukar serta di sepanjang garis pantai masih terdapat banyak sampah.

Hasil perbandingan secara visual misi ketiga Pantai Mutiara tahun 2019 dan tahun 2018 dapat dilihat pada gambar 12 dan gambar 13.

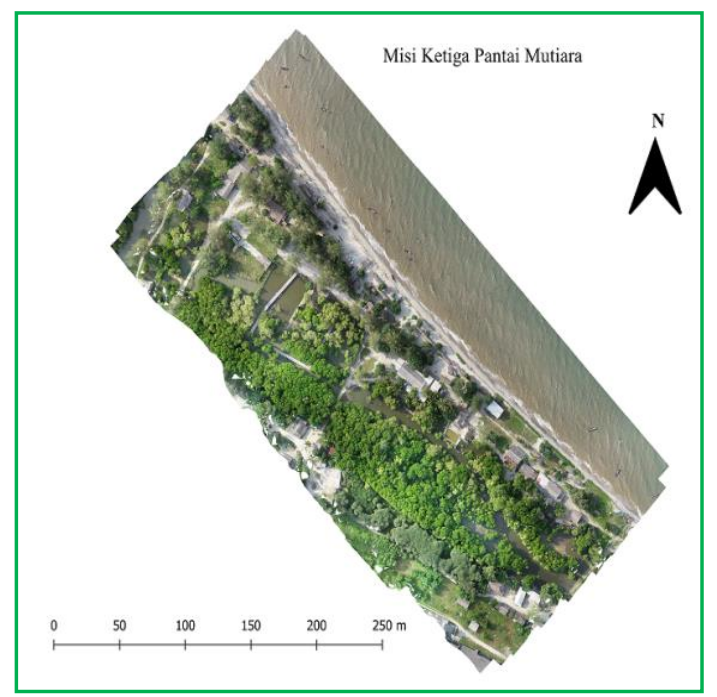

Gambar 12

Visualisasi Misi Ketiga Tahun 2019 


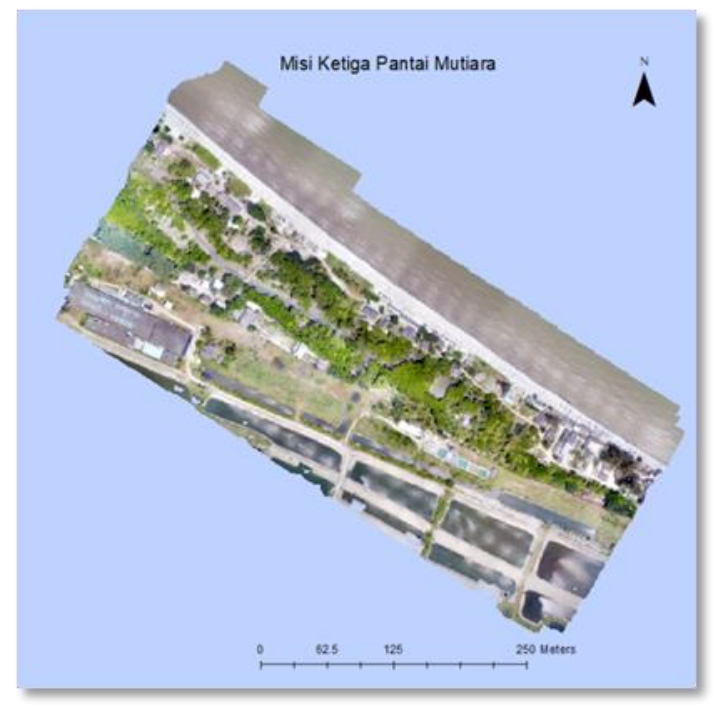

Gambar 13

Visualisasi Misi Ketiga Tahun 2018

Berdasarkan visualisasi pada tahun 2018 sudah mulai banyak pemukiman dan bangunan masyarakat yang berada pada sepanjang sempadan pantai. Zona garis pantai ini didominasi dengan pasir putih kering dan banyak masyarakat yang memanfaatkannya dengan area wisata. Sedangkan pada tahun 2019 masih didominasi oleh sampah di sepanjang garis pantai serta ada penambahan jumlah pondok wisata atau bangunan masyarakat.

\section{Kesimpulan}

Berdasarkan hasil dan pembahasan pada penelitian ini maka dapat disimpulkan bahwa dari evaluasi citra tahun 2019 diperoleh kesalahan jarak terkecil sebesar 0,0533 meter pada misi keempat dan kesalahan jarak terbesar sebesar 0,0757 meter pada misi pertama. Sedangkan pada tahun 2018 diperoleh kesalahan jarak terkecil sebesar 0,0739 meter pada misi ketiga.

Hasil uji ketelitian horizontal dan vertikal Peta Ortofoto tahun 2019 menunjukkan akurasi horizontal pada misi pertama sebesar 0,1124 meter, pada misi kedua sebesar 0,1086, pada misi ketiga sebesar 0,0833 meter, dan pada misi keempat sebesar 0,0743 meter. Adapun pada akurasi vertikal diperoleh nilai pada misi pertama sebesar 0,0262 meter, pada misi kedua sebesar 0,0259 meter, pada misi ketiga sebesar 0,0136 meter, dan pada misi keempat sebesar 0,0348 meter.

Hasil uji ketelitian horizontal dan vertikal ketiga Peta Ortofoto tahun 2018 menunjukkan akurasi horizontal pada misi pertama sebesar 0,1205 meter, pada misi ketiga sebesar 0,1056 meter, dan pada misi keempat sebesar 0,1337 meter. Adapun pada akurasi vertikal diperoleh nilai pada misi pertama sebesar 0,1080 meter, pada misi ketiga sebesar 0,1743 meter, dan pada misi keempat sebesar 0,2206 meter.

Visualisasi daerah zona pantai pada masing-masing misi memiliki karakteristik yang berbeda. Pada misi pertama, yaitu daerah yang berbatasan langsung dengan muara 
sungai ini memiliki daerah garis pantai berupa lumpur. Vegetasi pada zona ini berupa pohon mangrove dan beberapa bagian terdapat semak belukar. Pada misi kedua tahun 2018 daerah sepanjang garis pantai dipenuhi dengan sampah. Sampah ini berasal dari muara sungai yang didominasi oleh kayu dan sampah plastik. Sedangkan pada tahun 2019 didominasi oleh pepohonan dan semak belukar serta di sepanjang garis pantai masih terdapat banyak sampah.

Pada misi ketiga tahun 2018 sudah mulai banyak pemukiman dan bangunan masyarakat yang berada pada sepanjang sempadan pantai. Zona garis pantai ini didominasi dengan pasir putih kering dan banyak masyarakat yang memanfaatkannya dengan area wisata. Sedangkan pada tahun 2019 masih didominasi oleh sampah di sepanjang garis pantai serta ada penambahan jumlah pondok wisata atau bangunan masyarakat. Misi keempat sangat berbeda dengan misi lainnya karena pada daerah ini terdapat bangunan dermaga yang merupakan bagian dari tempat wisata. Pada daerah sekitarnya juga didominasi dengan bangunan masyarakat dan bangunan tanggul untuk meminimalisir ombak air laut. Namun pada tahun 2019 banyak pondok wisata yang sudah tidak terurus serta masih dijumpai sampah-sampah kayu di sekitar bangunan dermaga. Dan dijumpai pula karung-karung goni yang berisi pasir di pinggiran pantai. 


\section{BIBLIOGRAFI}

Agisoft, L. L. C. (2016). PhotoScan Python Reference. Release, 1 (3), 63. Google Scholar

Basith, A., Rokhmana, C. A., Kartini, C. N., Togatorop2Fitrawan, H., Pradanakusuma, D. P. A., Prayoga, T. S., \& Yudhono Prakoso \& Leksono, U. (2015). Pemetaan Pelabuhan Perikanan Pantai Sadeng Kabupaten Gunungkidul Menggunakan Uav. Prosiding Forum Ilmiah Tahunan Ikatan Surveyor Indonesia (FIT ISI), 19, 20. Google Scholar

Dahuri, R., Rais, J., Ginting, S. P., \& Sitepu, dan M. J. (2001). Pengelolaan sumberdaya wilayah pesisir dan lautan secara terpadu. PT. Pradnya Paramita. Jakarta, 328. Google Scholar

Drummond, C. D., Harley, M. D., Turner, I. L., A Matheen, A. N., \& Glamore, W. C. (2015). UAV applications to coastal engineering. Australasian Coasts \& Ports Conference 2015: 22nd Australasian Coastal and Ocean Engineering Conference and the 15th Australasian Port and Harbour Conference, 267. Google Scholar

Gonçalves, J. A., \& Henriques, R. (2015). UAV photogrammetry for topographic monitoring of coastal areas. ISPRS Journal of Photogrammetry and Remote Sensing, 104, 101-111. Google Scholar

Harintaka, S. T. (2012). Pengembangan Pemrosesan Fotogrametri Digital Foto Udara Format Kecil Untuk Penyediaan Data Spasial. Universitas Gadjah Mada. Google Scholar

Ibrahim, F. (2014). Teknik klasifikasi berbasis objek citra penginderaan jauh untuk pemetaan tutupan lahan sebagian kecamatan Mlati kabupaten Sleman. Universitas Gadjah Mada. Google Scholar

Junarto, R., Djurjani, D., Permadi, F. B., Ferdiansyah, D., Admaja, P. K., Sholikin, A. R., \& Rahmansani, R. (2020). Pemanfaatan teknologi unmanned aerial vehicle (uav) untuk pemetaan kadaster. BHUMI: Jurnal Agraria Dan Pertanahan, 6 (1). Google Scholar

Kolednik, D. (2014). Coastal monitoring for change detection using multi-temporal Lidar data. Proceedings of the CESCG, 73-78. Google Scholar

Maulana, E., Ambarwulan, W., Wulan, T. R., Saputro, G. B., Setiawan, N., Muharram, F. W., Mulia, W. N., Hendrastuti, B., Ibrahim, F., \& Putra, M. D. (2017). Evaluasi ODTW Pantai Kolbano untuk Peningkatan Ekonomi Lokal Masyarakat di Desa Kolbano, Kecamatan Kolbano, Kabupaten Timor Tengah Selatan. Google Scholar

Maulana, E., \& Wulan, T. R. (2015). Pemotretan Udara dengan UAV Untuk Mendukung Kegiatan Konservasi Kawasan Gumuk Pasir Parangtritis. Simposium Nasional Sains Geoinformasi IV. Google Scholar 
Purwanto, T. H. (2017). Pemanfaatan foto udara format kecil untuk ekstraksi digital elevation model dengan metode stereoplotting. Majalah Geografi Indonesia, 31(1), 73-89. Google Scholar

Putra, A. S., Maulana, E., Wulan, T. R., Nurhidayah, P., Sanjaya, M. D. A., \& Swastiko, F. A. (2016). Uji Akuisisi Data dengan UAV untuk Monitoring Kondisi Mangrove dalam Mencegah Abrasi Air Laut (Studi Kasus: Pesisir Baros, Tirtoargo, Kecamatan Kretek, Kabupaten Bantul). Google Scholar

Rokhmana, C. A. (2013). Percepatan Pemetaan Kadaster Memanfaatkan Teknologi Wahana Udara Tanpa Awak. Bhumi: Jurnal Agraria Dan Pertanahan, 38, 263-268. Google Scholar

Saadatseresht, M., Hashempour, A. H., \& Hasanlou, M. (2015). UAV photogrammetry: a practical solution for challenging mapping projects. The International Archives of Photogrammetry, Remote Sensing and Spatial Information Sciences, 40 (1), 619. Google Scholar

Zald, A. E., Summer, S., \& Wade, T. (2006). A to Z GIS: an illustrated dictionary of geographic information systems. Google Scholar

\section{Copyright holder:}

Dio Mega Putri, Ahmad Perwira Mulia (2021)

First publication right:

Jurnal Syntax Admiration

This article is licensed under:

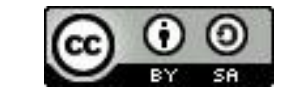

